\title{
Effects of Microstructures on Corrosion and Stress Corrosion Behaviors of an Al-12.1 at.\% Zn Alloy
}

\author{
M.S. Yeh, L.C. Tsao, and T.H. Chuang
}

(Submitted 4 January 2000; in revised form 5 April 2000)

\begin{abstract}
Various heat treatments of an Al-12.1 at.\% $\mathrm{Zn}$ alloy would bring forth various types of microstructures such as solid solution (SS), continuous precipitation (CP), and discontinuous precipitation (DP), each of which contain respective shares of distribution of the aluminum-rich phases $\left(\alpha_{0}, \alpha\right)$ and the zinc-rich phase $(\beta)$, and the corrosion behaviors of the said alloy may be affected as a result. Electrochemical measurements conducted in a 3 wt.\% NaCl solution indicate that respective corrosion rates should be evinced in the following order: supersaturated $\mathrm{SS}<\mathrm{DP}<\mathrm{CP}$. The difference in microstructures can also exert an influence on stress corrosion cracking (SCC) of the said alloy. Stress corrosion cracks propagate predominantly in an intercrystalline mode. However, the severe corrosion of precipitation sites may incur a change in crack propagation under applied stress. In that case, patches of transgranular fractures are found interspersed in the intergranular mode.
\end{abstract}

Keywords $\mathrm{Al}-12.1 \% \mathrm{Zn}$, aluminum alloy, electrochemical tests, microstructure, stress corrosion

\section{Introduction}

For many years, aluminum-zinc alloys have been a source of great interest in the field of engineering, owing much to their good workability, precipitation hardenability, low cost, and light weight in mechanical applications. ${ }^{[1]}$ Through appropriate thermomechanical treatments, desirable superplasticity with considerable deformation can be achieved under very low stress for these aluminum-zinc alloys. ${ }^{[2,3]}$ In corrosion engineering, aluminum-zinc alloys are also highly regarded as excellent sacrificial anodes for cathodic protection of submerged marine structures by dint of their high energy capacity and long service life. ${ }^{[4,5,6]}$ Moreover, because of their superior corrosion resistance and cathodic protection efficiency, aluminum-zinc alloys have been employed as galvanized coating on steel sheets, particularly for the automobile industry. ${ }^{[7]}$

It has been found that binary aluminum-zinc alloys with various $\mathrm{Zn}$ contents lead to different phase transformations after various heat treatments. Figure 1 demonstrates three types of microstructures for a precipitation-treated aluminum-zinc alloy. Solution treatment and quench by water give rise to a microstructure of a homogeneous matrix in the state of supersaturated single-phase solid solution (SS) $\alpha_{0}$, as shown in Fig. 1(a). Further aging at various temperatures in the duplex-phase regions, ${ }^{[8]}$ the supersaturated $\alpha_{0}$ SS will decompose into an aluminum-rich $\alpha$ phase and a zinc-rich $\beta$ phase. The morphology of such $(\alpha+\beta)$ mixtures varies, depending on the aging temperature. At higher aging temperatures, the $\alpha$ phase exists

M.S. Yeh, Department of Mechanical Engineering, Chung-Hua University, Hsin-Chu 300, Taiwan Republic of China; and L.C. Tsao and T.H. Chuang, Institute of Materials Science and Engineering, National Taiwan University, Taipei 106, Taiwan, Republic of China. as fine particulates (continuous precipitates), which uniformly disperse in the $\beta$ phase matrix, ${ }^{[9,10]}$ as shown in Fig. 1(b). The precipitates formed at grain boundaries are coarser, resulting in a precipitation-free zone (PFZ) near the grain boundaries. At lower aging temperatures, however, both the $\alpha$ and $\beta$ phases grow into lamellar structures to form cellular precipitates, which are initiated at grain boundaries and move into the grain interiors. ${ }^{[11,12,13]}$ Unless complete cellular reactions are achieved after a protracted period of aging time, the morphological pattern will display a coexistence of precipitated cells $(\alpha+\beta)$ and an undecomposed $\alpha_{0}$ matrix, as shown in Fig. 1(c). Since the zinc contents in $\alpha_{0}, \alpha$, and $\beta$ phases are different, various allocations and distributions of these phases in the three types of microstructures should render different effects on the mechanical and corrosion properties of the aluminum-zinc alloy. Furthermore, the $\alpha_{0}$ and $\alpha$ phases in this alloy possess a face-centered cubic (fcc) structure, while the $\beta$ phase is hexagonal close-packed (hcp). ${ }^{[8]}$ The ductile nature of an fcc phase versus the brittle character of an hcp phase should also influence the fracture behavior of the aluminum-zinc alloys after different heat treatments. On the other hand, it is well known that the precipitates can strengthen the alloys by impeding the dislocation movements while decreasing their corrosion resistance-a phenomenon attributed to those electrochemical local cells between the precipitates and the matrix. ${ }^{[14]}$ In view of such a strengthening effect, the continuous precipitates are recognized to be superior to the cellular precipitates. However, comparisons between the corrosion effects of these two types of precipitates have been scantily studied, though the role that continuous precipitates (especially those formed at grain boundaries) play in the SCC of aluminum alloys has been frequently discussed. ${ }^{[15-19]}$ It would be interesting to know if these discussions could be adapted for the cellular precipitates, as they also inhabit the realm of grain boundary regions. Thus, this study is concerned with the clarification of corrosion and stress corrosion behaviors of the three types of microstructures formed in an Al-12.1 at.\% $\mathrm{Zn}$ alloy. 


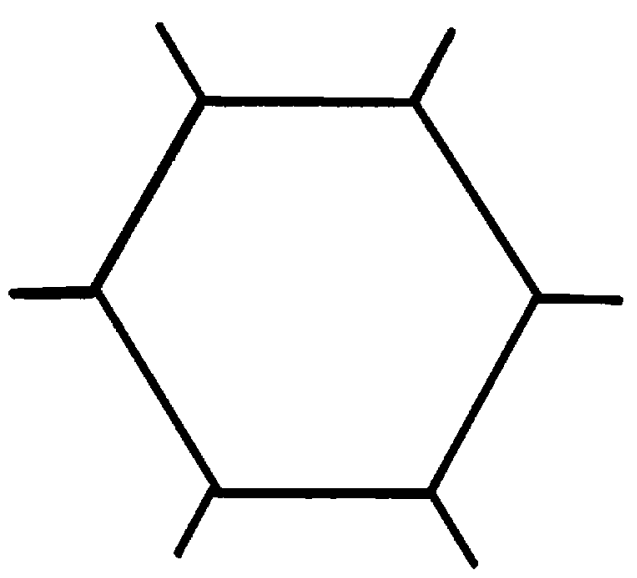

(a)

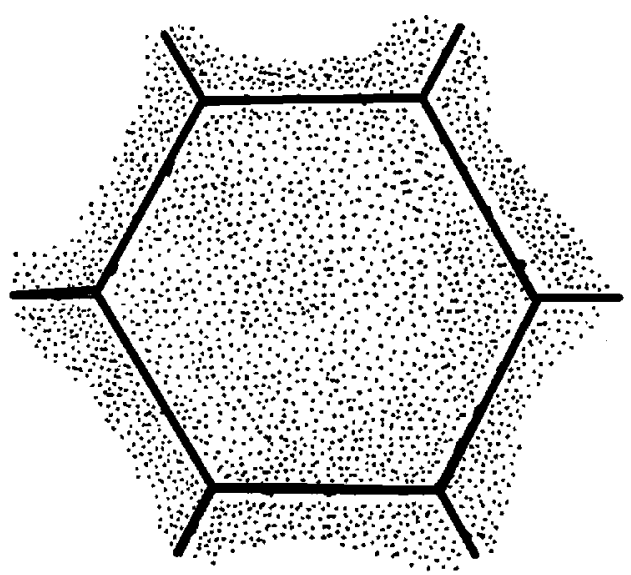

(b)

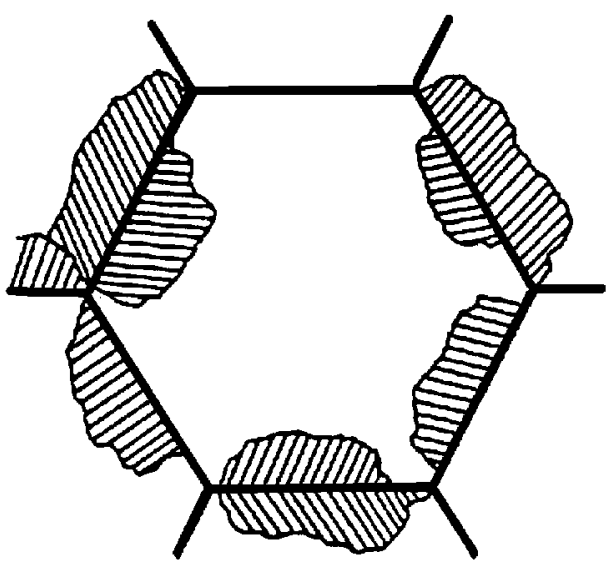

(c)

Fig. 1 Schematic representation of three types of microstructures of the Al-12.1 at.\% Zn alloy after various heat treatments: (a) supersaturated SS. (b) CP, and (c) DP

\section{Experimental}

The Al-12.1 at.\% Zn alloy used in this study was prepared by melting under argon atmosphere and casting into iron molds. These ingots were homogenized at $673 \mathrm{~K}$ for 10 days

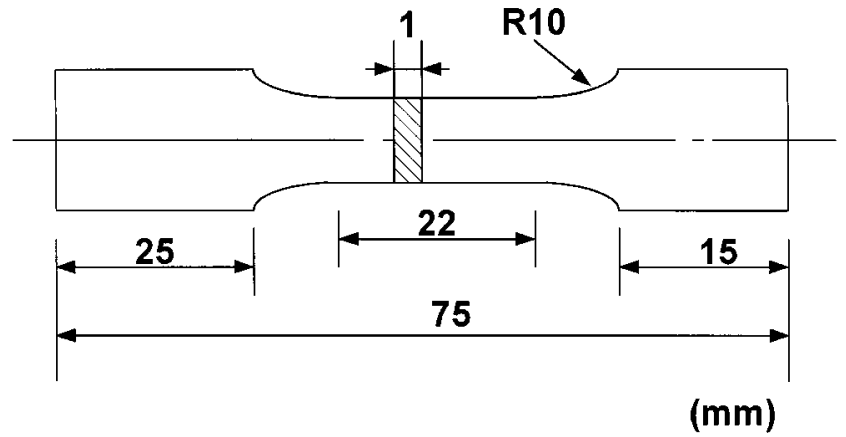

Fig. 2 Dimensions of specimens for SCC tests

and then rolled to $1 \mathrm{~mm}$ thick sheets. The grain size was about $200 \mu \mathrm{m}$. Experimental specimens were cut from the sheet material and the dimensions of specimens for stress corrosion testing were shown in Fig. 2. All specimens were solution-treated by heating at $673 \mathrm{~K}$ for $4 \mathrm{~h}$, followed by quenching in water to obtain the supersaturated SS. After the solution treatment, specimens were aged at $473 \mathrm{~K}$ for 7 days and at $373 \mathrm{~K}$ for $250 \mathrm{~h}$, which resulted in the decomposition of the supersaturated SS into continuous precipitates and discontinuous precipitates, respectively. The microstructures were observed with an optical microscope (OM) after etching in 1 wt. $\% \mathrm{NaOH}$ solution at $323 \mathrm{~K}$ for $30 \mathrm{~s}$.

The corrosion properties pertaining to the three different types of microstructures were examined at room temperature in a $3 \mathrm{wt} . \% \mathrm{NaCl}$ solution with a potentiostat. Before electrochemical tests, specimens were ground with 1000 grit $\mathrm{SiC}$ paper and cleaned in acetone. For dynamic polarization tests, the potential began at $-2000 \mathrm{mV}$ (versus standard calomel electrode (SCE)) and scanned in the noble direction to an anodic current density of $10^{4} \mu \mathrm{A} / \mathrm{cm}^{2}$ with a scanning rate of $1 \mathrm{mV} / \mathrm{s}$. Before the polarization tests, the corrosion potential $\left(\Phi_{\text {corr }}\right)$ of specimens was measured after immersion in the $\mathrm{NaCl}$ solution for $30 \mathrm{~min}$.

The SCC in a 3 wt. $\% \mathrm{NaCl}$ solution was studied with the aid of a constant load testing apparatus. Various stresses were applied to specimens, and the failure time of the specimens was recorded at the open-circuit potential. To evaluate the effects of the applied potential on SCC sensitivity, the time to failure for specimens with a fixed stress was measured at various potentials applied. The fracture surfaces after SCC were examined by a scanning electron microscope (SEM).

\section{Results and Discussion}

Typical micrographs of the Al-12.1 at.\% Zn alloy subjected to three different heat treatments were shown in Fig. 3. The grain size of the specimens was large at approximately $250 \mu \mathrm{m}$ after solution treatment at $673 \mathrm{~K}$ for $4 \mathrm{~h}$ (AlZn-SS, as shown in Fig. 3a). Upon further aging at $473 \mathrm{~K}$ for 7 days, continuous precipitates of the zinc-rich $\beta$ phase were formed uniformly in the matrix accompanied by precipitate-free zones (PFZs) near 

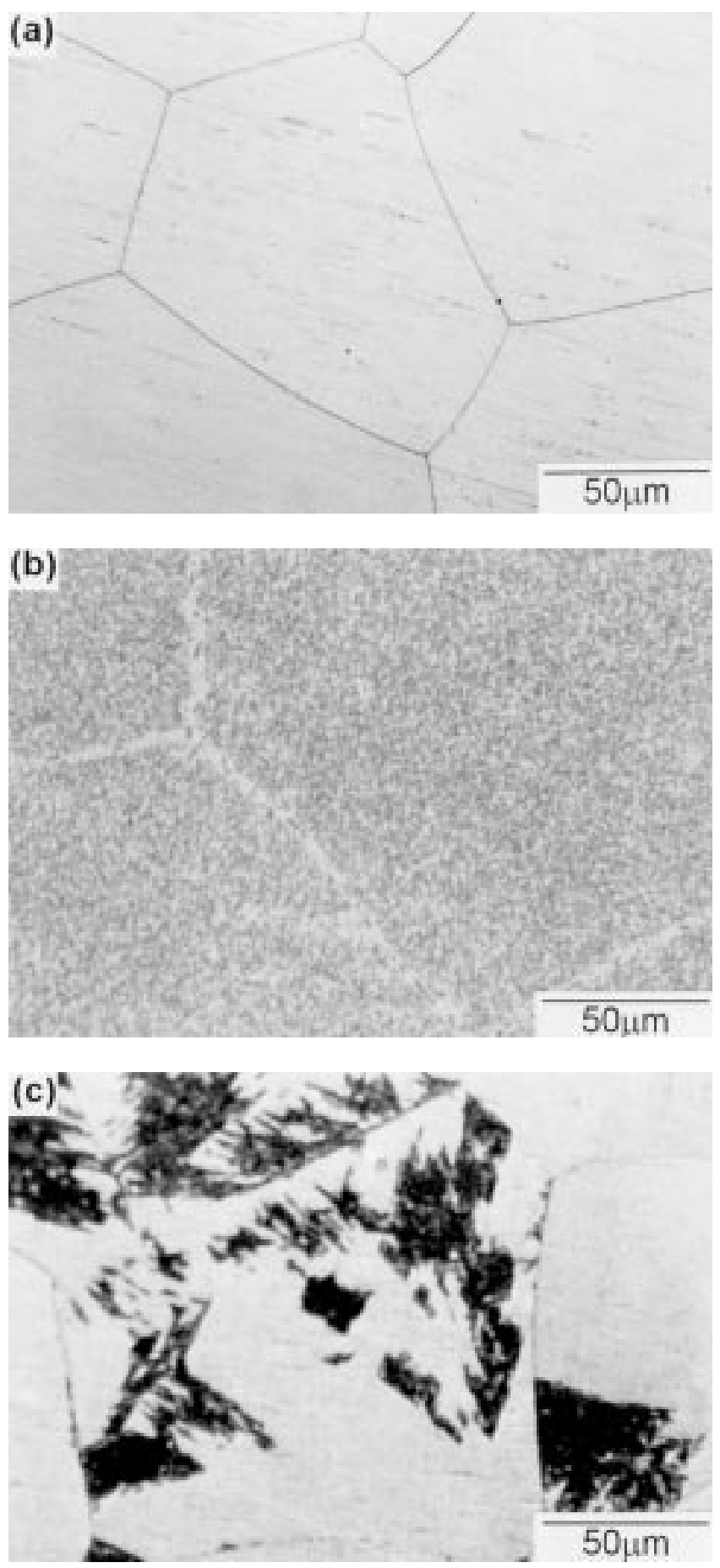

Fig. 3 Micrographs of Al-12.1 at.\% $\mathrm{Zn}$ alloy: (a) solution-treated $(673 \mathrm{~K}, 4 \mathrm{~h})$, (b) solution-treated and aged (473 K, 7 days), and (c) solution-treated and aged $(373 \mathrm{~K}, 250 \mathrm{~h})$

the grain boundaries. The width of PFZs was about 3 to $5 \mu \mathrm{m}$ (AlZn-CP, as shown in Fig. 3b). After aging at $373 \mathrm{~K}$ for 250 $\mathrm{h}$, cellular precipitates with a lamellar structure of $\alpha+\beta$ phases were grown from the grain boundaries into the grain interiors (AlZn-DP, as shown in Fig. 3c). The interlamellar spacing was about 1 to $2 \mu \mathrm{m}$ and the cell width was about $40 \mu \mathrm{m}$. With the aging time raised to $500 \mathrm{~h}$ at the same temperature, the
Table 1 Mechanical properties of the Al-12.1 at.\% Zn alloy after various heat treatments

\begin{tabular}{lccc}
\hline Specimens & $\begin{array}{c}\boldsymbol{\sigma}_{\text {UTS }} \\
\left(\mathbf{k} / \mathbf{m m}^{\mathbf{2}}\right)\end{array}$ & $\begin{array}{c}\boldsymbol{\sigma}_{\boldsymbol{y}} \\
\left(\mathbf{k} / \mathbf{m m}^{\mathbf{2}}\right)\end{array}$ & $\begin{array}{c}\boldsymbol{\sigma}_{\mathbf{S C C}} \\
\left(\mathbf{k} / \mathbf{m m}^{\mathbf{2}}\right)\end{array}$ \\
\hline SS & 9.6 & 7.8 & 2.3 \\
CP & 25.2 & 17.1 & 5.2 \\
DP & 20.4 & 14.2 & 3.7 \\
\hline
\end{tabular}

interlamellar spacing remained constant, while the cell width increased to about $100 \mu \mathrm{m}$, which implied that the cellular precipitates grew at a constant rate of about $0.25 \mu \mathrm{m} / \mathrm{h}$. For the Al-12.1 at.\% $\mathrm{Zn}$ alloy of various microstructures, Table 1 tabulated its mechanical properties $\left(\sigma_{\mathrm{UTS}}\right.$ and $\left.\sigma_{\mathrm{y}}\right)$.

From the dynamic polarization curves (Fig. 4), the corrosion potential $\left(\Phi_{\text {corr }}^{\prime}\right)$, the breakdown potential $\left(\Phi_{\mathrm{b}}\right)$, and the dynamic corrosion current density $\left(\mathrm{I}_{\text {corr }}\right)$ were determined and listed in Table 1. The width of the passive region on the anodic polarization curves $\left(\Delta \Phi\right.$ eq $\left.\Phi_{\mathrm{b}}-\Phi_{\text {corr }}^{\prime}\right)$ in Table 2 indicates the pitting resistibility or the stability of the passive film on the Al-Zn alloy surface. The corrosion potential $\left(\Phi_{\text {corr }}\right)$ measured before dynamic polarization is also listed in Table 1 . It was evident that specimens of the $\mathrm{CP}(\mathrm{AlZn}-\mathrm{CP})$ microstructure possessed the most active corrosion potential, while specimens of AlZnSS and AlZn-DP displayed similar corrosion potentials, which were less than that of AlZn-CP. Dynamic polarization results indicated that the sequence of corrosion rates was AlZn-SS $<$ AlZn-DP $<$ AlZn-CP. In the case of samples with a microstructure of the supersaturated SS, the zinc atoms dissolved into the aluminum SS. In this state, the matrix of the alloy possessed a uniform chemical composition. As a result, a perfect protective $\mathrm{Al}_{2} \mathrm{O}_{3}$ film formed on the sample surface and contributed to the lowest corrosion current density. As for the aged specimens, since zinc normally displayed a more active potential than aluminum in seawater, the existence of zinc-rich precipitates (of the $\beta$ phase) in the alloy (AlZn-CP or AlZn-DP) could incur an active corrosion potential tendency. As for the AlZn-CP specimens, the $\beta$ precipitates appeared as evenly distributed active particles, resulting in the most active corrosion potential of all. Although the $\beta$ phase also existed in DP specimens as lamellar precipitates, most of the matrix in AlZn-DP specimens was still held in supersaturated solutions, as shown in Fig. 3(c), which explained why its corrosion potential was similar to that of AlZn-SS specimens.

In this study, the SCC behavior of the Al-12.1 at.\% Zn alloy in a $3 \mathrm{wt} . \% \mathrm{NaCl}$ solution was also found to be influenced by its microstructures. Figure 5 showed the relationship between applied stress and failure time for the three types of microstructures of the Al-12.1 at.\% $\mathrm{Zn}$ alloy at open circuit potential. The failure time of all the specimens decreased with the increase of applied stress. The effect of applied potentials on the SCC behavior of the Al-12.1 at.\% Zn alloy, as possessed of various microstructures, is shown in Fig. 6. What was noticeable was that an anodic potential accelerated the SCC of the Al-12.1 at.\% Zn specimens (AlZn-SS, AlZn-CP, and AlZn-DP). When the same stress or anodic potential was applied to the AlZn$\mathrm{CP}$ specimens, their failure time could be stretched to the longest extent. This might be caused by precipitated particles dissolving 


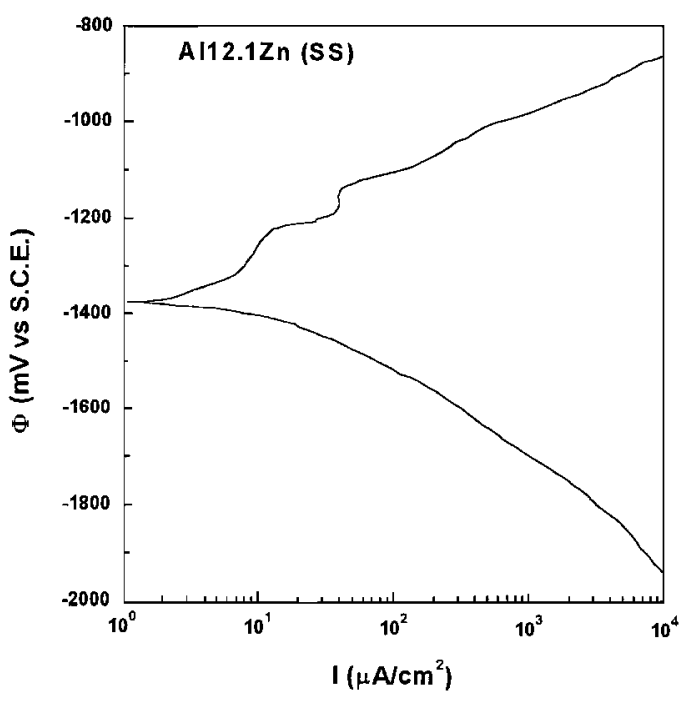

(a)

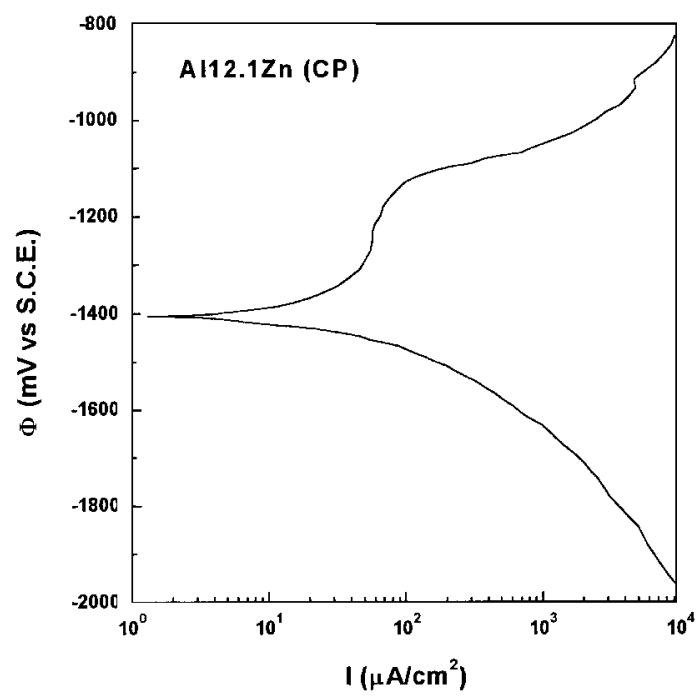

(b)

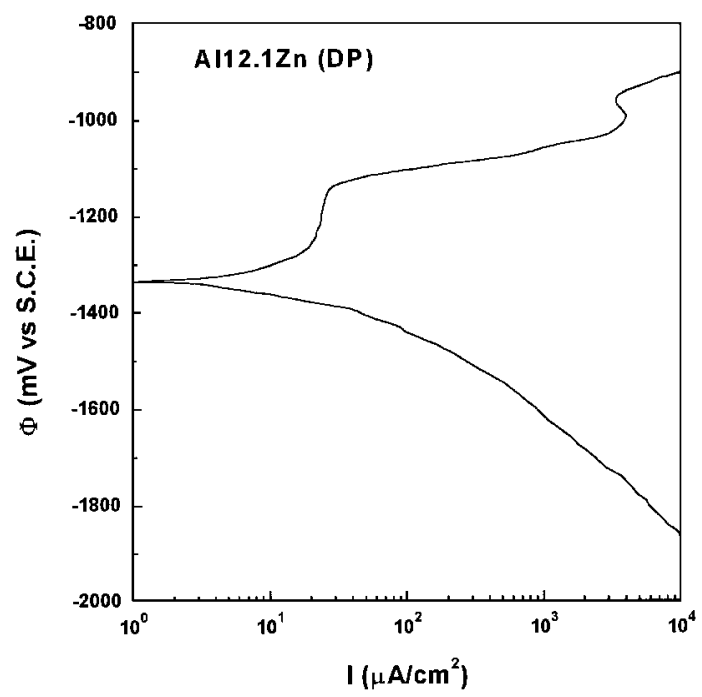

(c)

Fig. 4 Dynamic polarization curves of the Al-12.1 at.\% $\mathrm{Zn}$ alloy with various microstructures in a $3 \% \mathrm{NaCl}$ solution

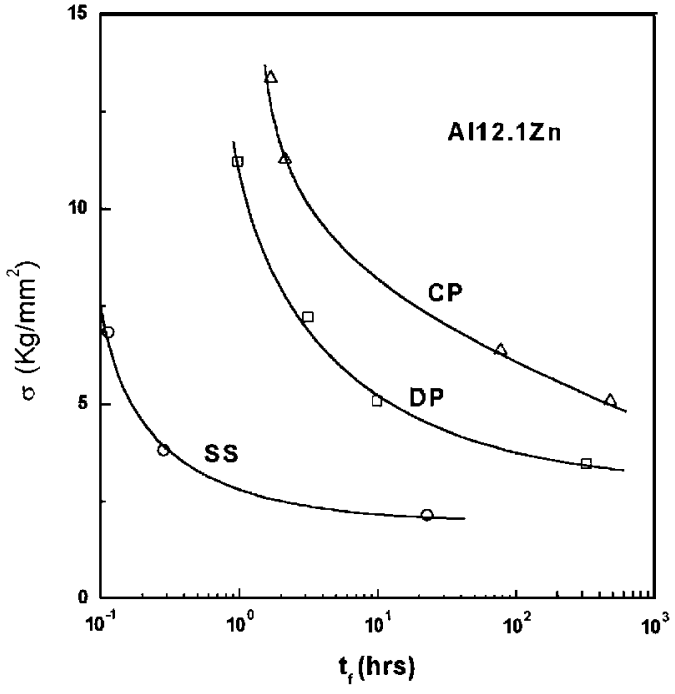

Fig. 5 Effect of applied stress $(\sigma)$ on failure time $\left(\mathrm{t}_{\mathrm{f}}\right)$ for the Al-12.1 at. $\% \mathrm{Zn}$ alloy with various microstructures in a $3 \%$ solution

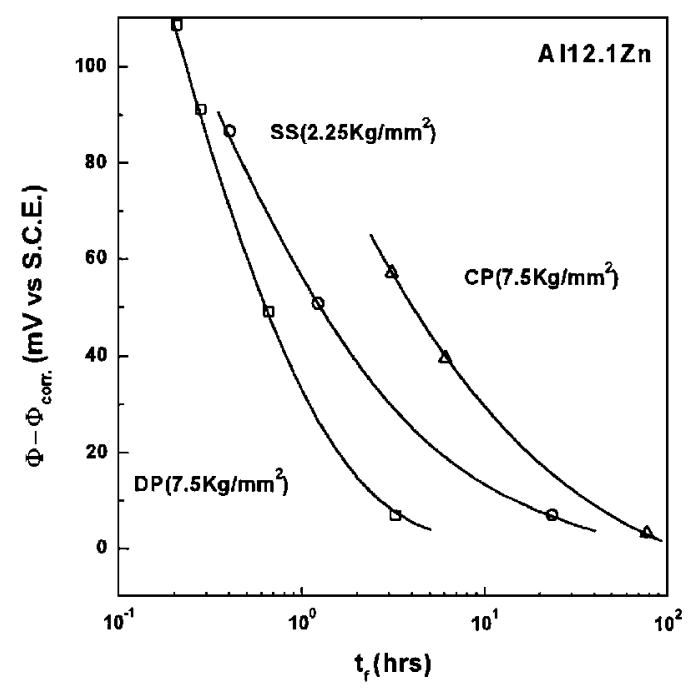

Fig. 6 Effect of applied potential $\left(\Phi-\Phi_{\text {corr }}\right)$ on failure time $\left(\mathrm{t}_{\mathrm{f}}\right)$ for the $\mathrm{Al}-12.1$ at.\% $\mathrm{Zn}$ alloy with various microstructures in a $3 \% \mathrm{NaCl}$ solution

in the 3 wt.\% $\mathrm{NaCl}$ solution and corrosion pores formed and evenly distributed in the matrix, which in turn released the stress concentration around the crack tip during the crack propagation process. In addition, precipitated particles retained in the interior of the matrix could also retard the propagation of cracking.

Typical stress corrosion fractography of AlZn-SS specimens is shown in Fig. 7. The cracks propagated predominantly in an intergranular mode. Since the AlZn-SS specimens exhibited the lowest yield strength ( $\sigma_{y}$ in Table 1$)$, any stress applied could produce a great number of slip lines on the surface of specimens, resulting in corrosion pits on the fracture surface, as shown in Fig. 7(a). These corrosion pits would be interlinked to form crack branches when an anodic potential was applied to the AlZn-SS specimens (Fig. 7b). In the case of the AlZn-CP specimens, the zinc-rich continuous precipitates were first dissolved in a $\mathrm{NaCl}$ solution. The corrosion sites of the precipitates 

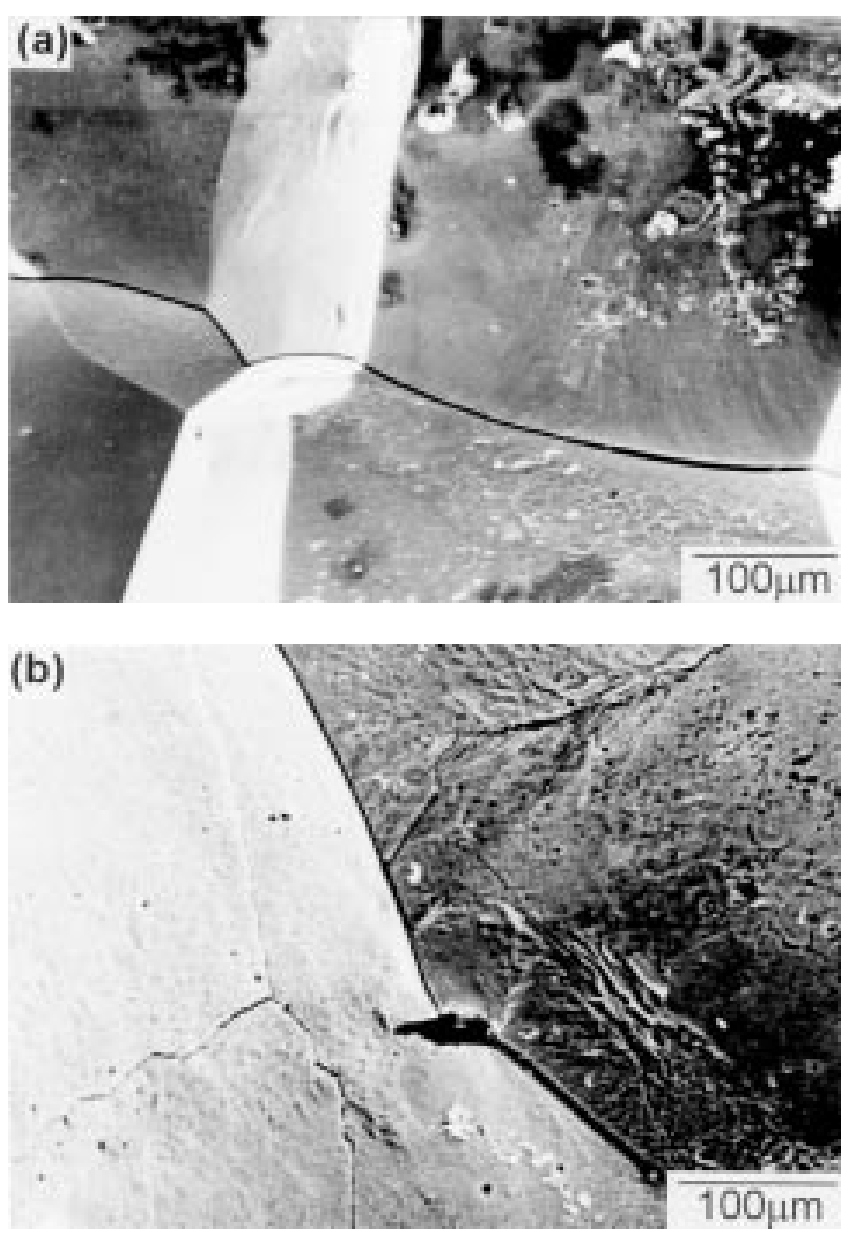

Fig. 7 SEM fractography of the AlZn-SS alloy in a 3\% $\mathrm{NaCl}$ solution: (a) applied stress $2.3 \mathrm{~kg} / \mathrm{mm}^{2}$; and (b) applied stress $2.3 \mathrm{~kg} / \mathrm{mm}^{2}$, applied potential $\Phi_{\text {corr }}+315 \mathrm{mV}$

Table 2 Corrosion properties of the Al-12.1 at.\% $\mathrm{Zn}$ alloy in a $3 \% \mathrm{NaCl}$ solution after various heat treatments

\begin{tabular}{|c|c|c|c|c|c|c|}
\hline Specimens & $\begin{array}{c}\text { Heat } \\
\text { Treatment }\end{array}$ & $\begin{array}{c}\boldsymbol{\Phi}_{\text {corr }} \\
\left(\mathbf{m V}_{\mathrm{SCE}}\right)\end{array}$ & $\begin{array}{c}\Phi_{\text {corr }}^{\prime} \\
\left(\mathbf{m V}_{\mathrm{SCE}}\right)\end{array}$ & $\begin{array}{c}\boldsymbol{\Phi}_{b} \\
\left(\mathbf{m} \mathbf{V}_{\text {SCE }}\right)\end{array}$ & $\begin{array}{c}\Delta \Phi \\
(\mathbf{m V})\end{array}$ & $\begin{array}{c}\boldsymbol{I}_{\text {corr }} \\
\left(\boldsymbol{\mu} \mathbf{A} / \mathbf{c m}^{2}\right)\end{array}$ \\
\hline SS & 673 K, WQ & -965 & -1355 & -1035 & 320 & 1.34 \\
\hline $\mathrm{CP}$ & $\begin{array}{l}673 \mathrm{~K}, \mathrm{WQ}+ \\
473 \mathrm{~K}, 7 \text { days }\end{array}$ & -998 & -1407 & -1127 & 280 & 11.20 \\
\hline DP & $\begin{array}{l}673 \mathrm{~K}, \mathrm{WQ}+ \\
373 \mathrm{~K}, 250 \mathrm{~h}\end{array}$ & -962 & -1351 & -1167 & 184 & 7.27 \\
\hline
\end{tabular}

$\Phi_{\text {corr }}$ : corrosion potential, $\Phi_{\text {corr }}^{\prime}:$ dynamic corrosion potential, $\Phi_{b}:$ breakdown potential, $\Delta \Phi$ : dynamic passive range $\left(=\Phi_{\mathrm{b}} \quad \Phi_{\text {corr }}^{\prime}\right) I_{\text {corr }}$ : corrosion current density WQ: water quenched.

would evolve further on through chemical attacking and form corrosion pipes, which would bestow more stress across the plane due to a reduction in the cross-sectional surface of specimens. Figure 8(a) shows the tunnel-like figurations of the stress corrosion fracture surface of the AlZn-CP specimens in a 3 wt. $\% \mathrm{NaCl}$ solution. An anodic potential accelerated the dissolution of precipitates, and in this case, patches of transgranular
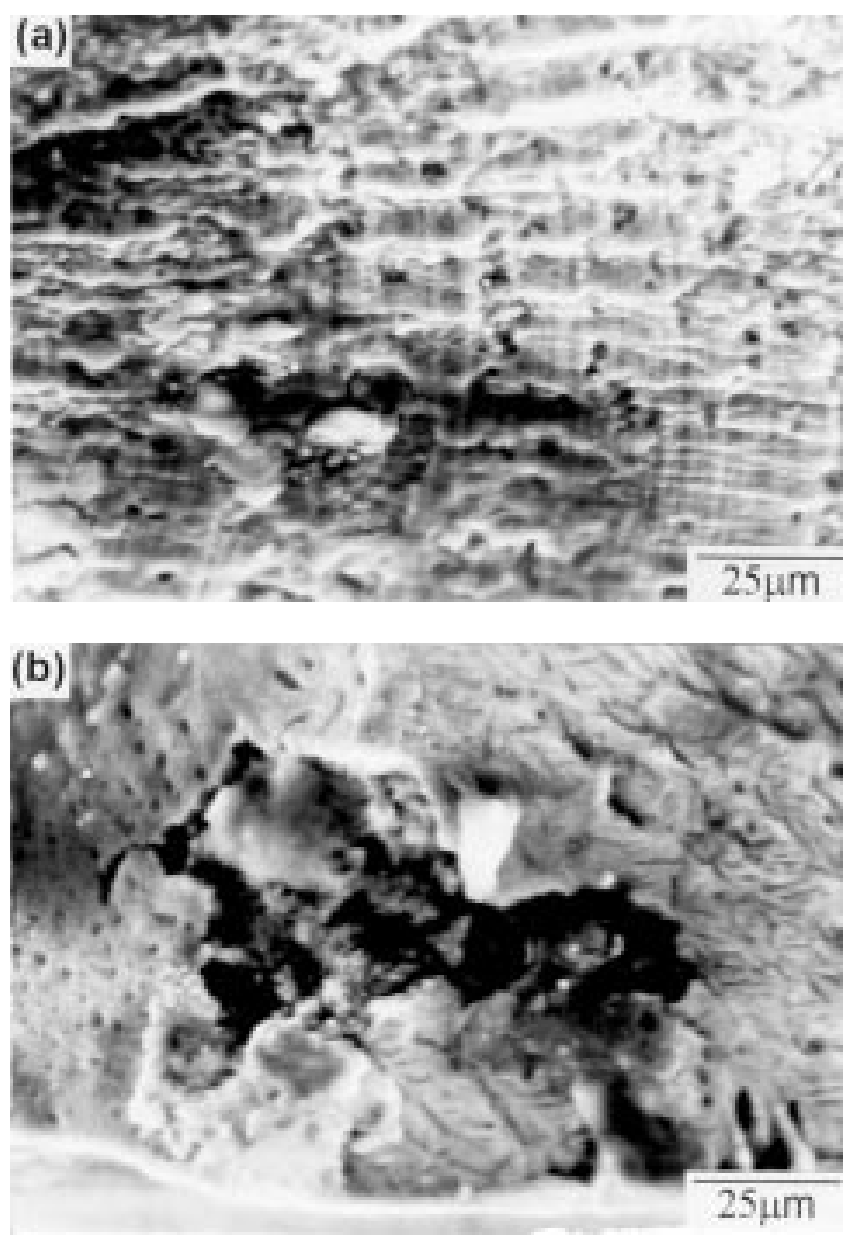

Fig. 8 SEM fractography of the $\mathrm{AlZn}-\mathrm{CP}$ alloy in $3 \% \mathrm{NaCl}$ solution: (a) applied stress $7.5 \mathrm{~kg} / \mathrm{mm}^{2}$; and (b) applied stress $7.5 \mathrm{~kg} / \mathrm{mm}^{2}$, applied potential $\Phi_{\text {corr }}+120 \mathrm{mV}$

fractures were found blended into the intergranular mode, as shown in the stress corrosion fractography of the AlZn-CP specimens (Fig. 8b). On the other hand, cellular precipitates were formed around the grain boundaries of the AlZn-DP specimens. Since the regions of cellular precipitates exhibited a more active corrosion potential and a lower hardness in comparison with the undecomposed matrix, the stress corrosion cracks propagated preferably across the cellular precipitates regions, as shown in Fig. 9(a). During the anodic polarization, the large potential difference between the lamellar precipitates and the supersaturated SS's caused dramatic dissolution of the lamellar precipitates, and deep grooves were found near the grain boundaries of the AlZn-DP specimens, as shown in Fig. 9(b). In this case, anodic dissolution did play a significant role in the SCC of the Al-12.1 at.\% $\mathrm{Zn}$ specimens with DP.

\section{Conclusions}

The Al-12.1 at.\% $\mathrm{Zn}$ alloy with a microstructure of $\mathrm{CP}$ possesses the most active corrosion potential due to the existence of zinc-rich particles in the matrix. The corrosion rates 

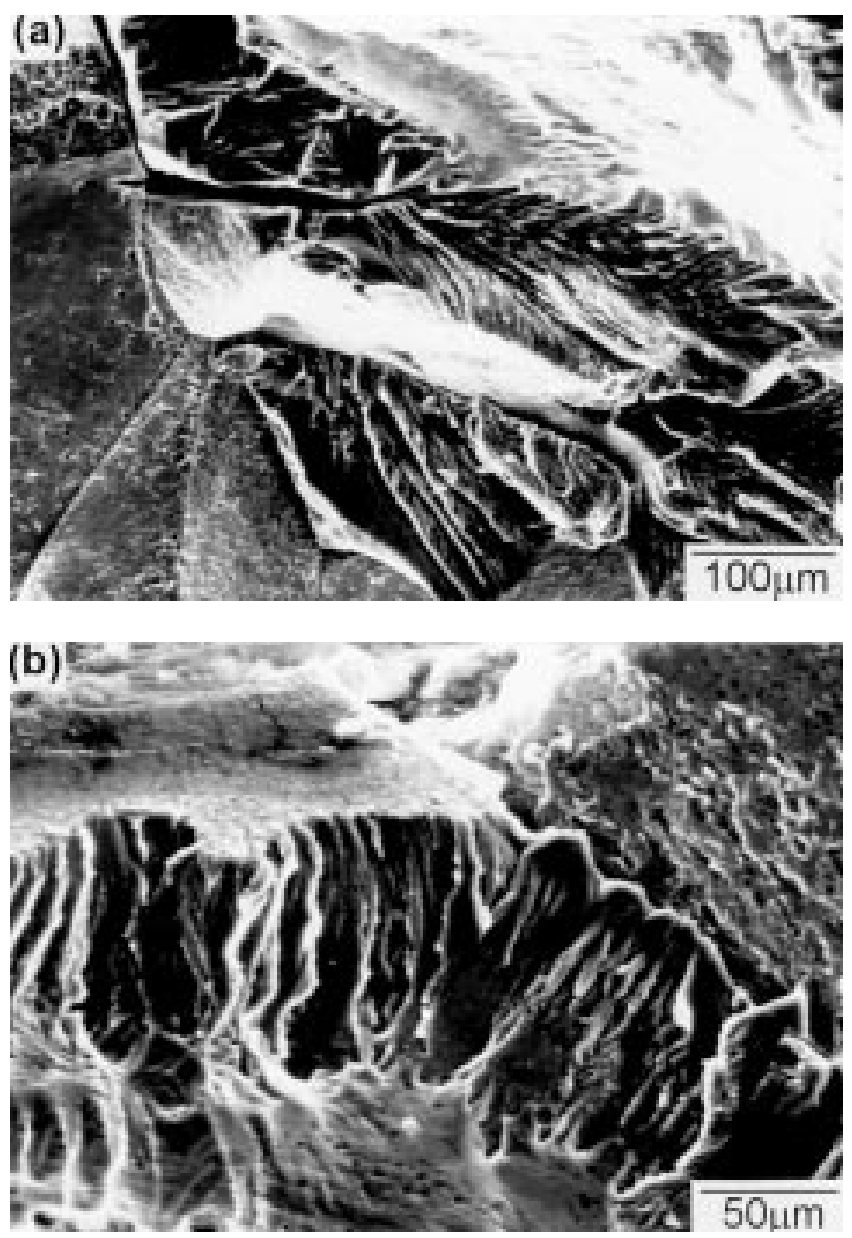

Fig. 9 SEM fractography of the AlZn-DP alloy in a $3 \% \mathrm{NaCl}$ solution. (a) applied stress $7.5 \mathrm{~kg} / \mathrm{mm}^{2}$; and (b) applied stress $7.5 \mathrm{~kg} / \mathrm{mm}^{2}$, applied potential $\Phi_{\text {corr }}+430 \mathrm{mV}$

of the Al-12.1 at.\% $\mathrm{Zn}$ alloy in a 3 wt.\% $\mathrm{NaCl}$ solution can be expressed in the following sequential order: AlZn-SS $<\mathrm{AlZn}$ DP $<$ AlZn-CP. The specimens of supersaturated SS possess uniform chemical compositions in the matrix and, thus, manifest the lowest corrosion rate.

The SCC behavior of the Al-12.1 at.\% $\mathrm{Zn}$ alloy in a 3 wt.\% $\mathrm{NaCl}$ solution is also influenced by its microstructures. Among these specimens, the AlZn-CP specimens display the longest failure time when applied with the same stress or anodic potential. On the other hand, the stress corrosion cracks of AlZn-SS specimens propagate predominantly in an intergranular mode. Tunnel-like appearances are found on the stress corrosion fractography of AlZn-CP specimens. Since the AlZn-DP specimens possess cellular precipitates near the grain boundaries, the stress corrosion cracks propagate preferably across the cellular precipitates regions and deep grooves are found near the grain boundaries of AlZn-DP specimens during the anodic polarization.

\section{Acknowledgments}

The authors thank the National Science Council, Taiwan, for the sponsorship of this study under Grant No. NSC88-2622E002-004.

\section{References}

1. "Aluminum Properties and Physical Metallurgy", J.E. Hatch, ed., ASM, Metals Park, OH, 1984, p. 347.

2. M. Hirohashi and H. Asanuma: J. Jpn. Inst. Light Met., 1988, vol. 38 (3), p. 159.

3. L. Gao: Proc. Int. Conf. on Superplasticity in Advanced Materials, Osaka, Japan, June 3-6, 1991, S. Hori, M. Tokizane, and N. Furushiro, eds., The Japan Society for Research on Superplasticity (JSRS), Suita, Osaka, Japan, 1991, p. 681

4. M.C. Reboul, P.H. Gimeneg, and J.J. Rameau: Corr. NACE, 1984, vol. 41 (7), p. 366.

5. A.H. AlSaffer, V. Ashworth, W.A. Grant, and R.P.M. Procter: Corr Sci., 1978, vol. 18, p. 687.

6. A.R. Despic, D.M. Drazic, M.M. Purenovic, and N. Cikovic: J. Appl. Electrochem., 1976, vol. 6(6), p. 527.

7. K.L. Lin, C.F. Yang, and J.T. Lee: Corr. NACE, 1991, vol. 47 (1), p. 9

8. Binary Alloy Phase Diagrams, American Society for Metals, Metals Park, OH, 1987, p. 184.

9. V. Melhortha and K.B. Rundman: Metall. Trans., 1972, vol. 3, p. 1551

10. K.N. Melton and J.W. Edington: Acta Metall., 1974, vol. 22, p. 1457.

11. C.P. Ju and R.A. Fournelle: Acta Metall., 1985, vol. 33, p. 71.

12. E.P. Butlev, V. Ramaswamy, and P. Swan: Acta Metall., 1973, vol. 21, p. 517.

13. M. Vigayalakshim, V. Seetharam, and V.S. Raghunathan: Acta Metall., 1982, vol. 30, p. 1147.

14. J.J. Thompson, E.S. Tankins, and V.S. Agarwala: Mater. Performance, 1987, June, p. 45.

15. M.O. Speidel: Metall. Trans., A, 1975, vol. 6A, p. 631.

16. P.K. Poulose, J.E. Morral, and A.J. Mcevily: Metall Trans., 1974, vol. 5, p. 1393.

17. J.K. Park and A.J. Ardell: Metall. Trans., A, 1984, vol. 15A, p. 1531.

18. D. Nguyen, A.W. Thompson, and I.M. Bernstein: Acta Metall., 1987, vol. 35 , p. 2417.

19. K. Rajan, W. Wallance, and J.C. Beddoes: J. Mater. Sci., 1982, vol 17, p. 2817 